\title{
Project Based Learning in Teaching Communication Skills in English as a Foreign Language to Engineering Students
}

\author{
http://dx.doi.org/10.3991/ijet.v11i04.5416 \\ Yu.Yu. Kovalyova ${ }^{1}$, A.V. Soboleva ${ }^{2}$ and A.T. Kerimkulov ${ }^{1}$ \\ ${ }^{1}$ National Research Tomsk Polytechnic University, Tomsk, Russia \\ ${ }^{2}$ National Research Tomsk State University, Tomsk, Russia
}

\begin{abstract}
The aim of this paper is to consider project based learning as one of the most efficient and productive methods used in teaching English as a foreign language to engineering students of Russian technical universities. Special emphasis is put on communication skills to be mastered by future engineers through project based learning. It is of great importance to note that highly developed oral and written communication skills are valuable for engineering students wishing to become successful and competitive in the international arena. Hence, engineering students must be trained well to develop their communication skills in English in the field of professional activity, mainly in the science research area. An inter-disciplinary project designed on the basis of project based learning for the second year students of Tomsk Polytechnic University is reviewed in this work. The authors come to the conclusion that project based learning is an ideal teaching method since it allows engineering students to improve significantly their oral and written communication skills as well as apply the content knowledge in the field of their professional activity within the English language course.
\end{abstract}

Index Terms - communication skills, project based learning, inter-disciplinary project work, science research area of engineering activity.

\section{INTRODUCTION}

Engineering graduates require an ever-increasing range of skills to maintain relevance with the global environment of the new millennium [1]. Thus, communication skills are regarded as essential and valuable for global engineers to become successful in the global arena.

It is common knowledge that more and more international projects tend to appear worldwide involving engineers from different parts of the world to perform their activities internationally. Therefore English is considered to be the prime means for communication between people who belong to different cultures and whose mother tongue is not English.

Foreign language communication of a future engineer is realized in a number of spheres of professional activity, such as science research, research and development, engineering and manufacturing, and organizationalmanagement [2].

At present, higher educational institutions of the Russian Federation make a lot of efforts to train engineering students to perform their future professional activity in the above mentioned spheres in compliance with the global engineering standards. They strive persistently to put undergraduates into authentic (academic exchange programmes, apprenticeships, double-degree programmes in a partner-university, etc.) or simulated contexts (EFL classes, extra-curricular activities, electronic learning courses, conferences and contests, etc.) which require them to use English as a foreign language (EFL) to pursue educational, research, and professional interests.

Yet there is evidence that graduate engineers still lack the required standard of EFL communication skills whether in the spoken or written mode. For example, the Tomsk Polytechnic University engineering graduates, when questioned, stated that they had poor knowledge of how to communicate effectively in English especially when asked about their future educational and research career plans. The graduates' performance in English was restricted to production of some sentences about the educational institutions where they had received their bachelor degrees, names of the completed course programmes and the professional fields they were intended to operate in future. Additionally, about $70 \%$ of the surveyed graduates admitted it was rather challenging for them to deal with the interviewer's questions about research projects they would be interested to do in future and what research interests they had at that time. It may seem that any technical university graduate can easily cope with this kind of task. However, it should be stated that a majority of Russian engineering undergraduates are deficient in the ability to define their research career prospects, and, consequently, are not prepared to discuss their science research interests in English.

\section{Project Based Learning In TEAChing ENGLish AS A FOREIGN LANGUAGE}

In reality Russian engineering students have limited chances to be taught by or communicate with English native speakers or practice their language skills in real life settings. Moreover, technical institutions' English language courses do not usually exceed the amount of 256 academic hours covered within one or two academic years.

To deal with these challenges, EFL teachers need to employ an appropriate teaching and learning method which allows learners both to develop communication skills and practice the content knowledge in professionally oriented contexts. 
In this respect, project based learning (PBL) is considered to be one of the methods which enables EFL teachers to minimize or even totally overcome the above mentioned challenges for a number of reasons.

First, PBL is a dynamic approach to teaching in which students explore real-world problems and challenges, simultaneously developing cross-curriculum skills while working in small collaborative groups or individually [3]. Second, learning through PBL becomes fruitful for learners because they exhibit their abilities to plan, manage, and accomplish projects through their content knowledge and language skills [4]. Thirdly, PBL is considered as student-centred since students are driven by the need to create an end-product which brings them opportunities to develop their confidence and independence in learning EFL [5]. Finally, another advantage of PBL in an English language classroom lies in the transfer of responsibility for the management of learning from teacher to learners [6].

\section{RESEARCH METHODOLOGY}

PBL as a way of ensuring genuinely communicative uses of spoken and written English [7] was introduced in the English curriculum for undergraduate engineering students studying in TPU whose level of EFL competence was stated as B1 in accordance with [8].

The project occupied four weeks of an EFL course's time with two classes in a week in addition to the learners' individual work outside the classes.

The study included 12 undergraduate students, 9 males and 3 females, majoring in Instrument Engineering and Electronics and Nanoelectronics and enrolled in an EFL course at Tomsk Polytechnic University during the third semester of the 2015 academic year. All the students were the second-year students with an average age of 19.

PBL in a form of an interdisciplinary-based project was offered to the students to help them apply content knowledge in their field of study and language skills as well as to develop their motivation and self-confidence in using EFL with the great emphasis on speaking and writing skills.

The project was done on the basis of the didactic material introduced in the course book which is naturally designed for future engineers already carrying out their scientific and research activity [9]. We were driven by the assumption that the implementation of this material accompanied by a variety of assignments would, on the one hand, enlarge the vocabulary relevant to the science research sphere of communication and, on the other hand, enable the students to acquire skills to communicate effectively and adequately in EFL in the field of their professional activity.

In this project work, there were several aims to be achieved by the students. (1) To enlarge the learners' vocabulary knowledge so that they could perform well in both spoken and written communication in the science research area. (2) To improve learners' speaking and writing skills enabling them to fulfill their communicative potentials when carrying out research work individually or in collaboration with others. (3) To develop learners' listening and reading skills allowing them to work with a wide range of sources of information in order to design their own research projects in a relevant area of professional interest.

\section{PRACTICAL IMPLEMENTATION OF THE INTER-} DISCIPLINARY PROJECT WITHIN ENGLISH AS A FOREIGN LANGUAGE COURSE

The inter-disciplinary project named as 'My research career path' was divided into four main stages each having its particular goal to be achieved.

The first stage under the name of 'Planning your educational and research career' included a number of assignments consequently performed by the students. They are as follows:

1. Comparing and contrasting similarities and distinctive characteristics of the systems of higher education in the countries of the European Union, the USA and Russia.

2. Scrutinising reading sources to identify and analyse possibilities for foreign students to receive grants to continue their educational and/or research career in another country.

3. Preparing short reports on educational programmes students are currently enrolled on in their alma mater.

4. Making up power point presentations of a foreign university students wished to continue their educational and research activities in future which involved searching for information about education programmes and academic disciplines of the target university, length and training fee, financial aid from the chosen university, as well as up-to-date scientific and research developments conducted by the university's teaching staff and students. Each student had half a week to work on the presentation before performing in the class.

Once the students were aware of how to communicate their educational and research career plans in English they could move to the second stage of the project work named as "Applying for research funding". The learners were asked to write an application form to take part in an imaginary competition to receive a research grant. They were facilitated to undertake the study of national and international funds and organisations which award grants to young scientists and researchers worldwide. A series of tasks was offered to the students to do before they presented their final drafts of application forms. First, the students were introduced to an authentic sample of application form and got acquainted with its sections. Second, they formed pairs to discuss content of each of the sections on the form and filled them with personal information. Finally, the learners were advised to focus attention on the section of the form which requested them to write up a project summary of their proposed research.

It is of importance to note that this task turned out to be both fascinating and challenging for the students to do. On the one hand, they became genuinely motivated in learning how to apply for research funding. But, on the other hand, the learners found it rather complicated to think about and give a description of a research project they would like to carry out in future. Initially, the students faced difficulties in defining their research interests, and as a result, providing a brief summary of aims, significance, and expected outcomes of the research plans.

However, after some period of practical work the students managed to write up their project summaries using between 150-180 words and present them in the class which was organized in a form of the simulated contest 
where participants acted both as candidates to win a research grant and experts who evaluated and commented on their peers' performances.

At the third stage 'Writing up a resume' the students were trained to write up a resume to find a job in science. Before this, the learners were questioned whether they had any previous experience in preparing resume in their native or target language. It was found out that almost $100 \%$ of the students admitted they had no any previous experience. However, all of them stressed the importance of obtaining skills to write up a resume as this would help them arrange documents when applying to a foreign university to continue their educational or research career in.

Preparation for writing up a resume was comprised of a series of tasks done by the students in the class which included:

1. Studying the list of resume headings such as personal information, education, research experience, dissertations, grants and awards, teaching experience, publications, presentations, computer skills, study abroad, technical skills, travel.

2. Organizing the list of headings in the best possible order.

3. Making suggestions for information to be included under each of the headings.

4. Getting acquainted with the best samples of resume in English presented in the original textbooks or Internet resources.

After the preparatory work was done the students were encouraged to compile their first drafts which were subject to peer assessment by both students and the lecturer. There were a number of errors revealed through assessment which were mostly connected with the lack of information under some of the resume headings or wrong order of the headings. As a result, the students were requested to make necessary changes to what they had written before and introduce their final drafts for another act of peer assessment.

The fourth and final stage of the project work named as 'Preparing for an interview' suggested developing students' skills to deliver a short presentation of their research proposal at interview. The students were asked to imagine a situation when they were invited for an interview by conference call which aimed at selecting the best candidate to receive a research grant. Bearing this in mind, students were fostered to browse reading resources to find information about the latest national and international scientific and technological achievements, choose a topic in their own research area and plan a three-minute video presentation of their proposed research which would focus on technology or product they could possibly design, improve or modify. The learners were given a week to prepare their videos and upload them to YouTube (https://www.youtube.com/channel/UC4A3gXWzwKW3 GW0YLZov- w/videos).

Finally, there were 12 video presentations of the students' proposed research uploaded to the specially created YouTube channel which covered such themes as: (1) Development of a technology to extend the load device's service life. (2) Design of a tonometer. (3) Design of a device to detect toxic substances in food and drinks. (4) Development of drilling rig sensory system. (5) Design of a smartphone thermal imager. (6) Development of 3D holographic advertising. (7) Development of a mobile robot to detect precious metals under the ground. (8) Improvement of the existing technology for artificial blood development. (9) Improvement of the existing laser cutting technology. (10) Development of a biodegradable flexible screen used in electrical devices production. (11) Development of radiographic weld inspection. (12) Modification of atomic-force microscopy.

It is worth mentioning that peer assessment was done at this stage of the given project in addition to writing comments on peers' videos which is thought to be a vital component of EFL learning as engineering students frequently reveal their reluctance to give low marks for poor work from their peers [1, p. 96], specify any advantages or disadvantages or give recommendations to their groupmates for further improvement.

The uploaded videos were assessed by the lecturer as well as the students in accordance with the selected criteria. They are as follows: (1) memorizing the script; (2) speed; (3) tone of voice; (4) pausing; (5) pronunciation; (6) position, mime and gestures; (7) knowledge of subject; (8) vocabulary; (9) structure; (10) coherence and cohesion.

According to the conditions of the contest, the student with the highest average score was chosen to be a winner at this stage of the project work.

\section{RESULTS AND OBSERVATIONS}

The findings (see Table 1) allowed us to conclude that the students' inter-disciplinary project works on the topic of "My research career path" were performed at a good level and on the whole received positive evaluation from the teacher as well as from the peers: $42 \%$ of the students received the 'excellent' grades, whereas $33 \%$ and $25 \%$ of the students received the 'good' and 'satisfactory' grades respectively.

TABLE I.

GRADING OF THE INTER-DISCIPLINARY PROJECT WORK 'MY RESEARCH CAREER PATH'

\begin{tabular}{|c|c|c|c|c|c|c|}
\hline 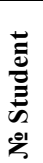 & $\begin{array}{c}\text { S1 } \\
\text { (max3 } \\
\text { pts.) }\end{array}$ & $\begin{array}{c}\text { S2 } \\
\text { (max.2 } \\
\text { pts.) }\end{array}$ & $\begin{array}{c}\text { S3 } \\
\text { (max.2 } \\
\text { pts.) }\end{array}$ & $\begin{array}{c}\text { S4 } \\
\text { (max.3 } \\
\text { pts.) }\end{array}$ & $\begin{array}{c}\text { Total } \\
\text { score } \\
\text { (max. } \\
10 \\
\text { pts.) }\end{array}$ & $\begin{array}{l}\text { Final } \\
\text { grade }\end{array}$ \\
\hline 1 & 3.0 & 1.9 & 2.0 & 2.6 & 9.5 & excellent \\
\hline 2 & 3.0 & 1.6 & 1.8 & 2.7 & 9.1 & excellent \\
\hline 3 & 3.0 & 1.7 & 1.7 & 2.7 & 9.1 & excellent \\
\hline 4 & 3.0 & 1.7 & 1.8 & 2.5 & 9.0 & excellent \\
\hline 5 & 2.7 & 1.8 & 2.0 & 2.4 & 8.9 & excellent \\
\hline 6 & 2.5 & 1.9 & 1.6 & 2.8 & 8.5 & good \\
\hline 7 & 2.9 & 1.4 & 1.6 & 2.4 & 8.3 & good \\
\hline 8 & 2.6 & 1.7 & 1.2 & 2.0 & 7.5 & good \\
\hline 9 & 1.7 & 1.7 & 1.7 & 2.3 & 7.4 & good \\
\hline 10 & 2.4 & 1.6 & 1.5 & 1.8 & 7.3 & satisfactory \\
\hline 11 & 2.1 & 1.3 & 1.6 & 2.2 & 7.2 & satisfactory \\
\hline 12 & 1.5 & 1.4 & 1.3 & 1.8 & 6.0 & satisfactory \\
\hline
\end{tabular}

Note: S stands for Stage. For example, S1 represents Stage 1 of the project.

To get a feedback from the students about the project work, they were offered to fill out a questionnaire designed with the help of Google service and included 10 close-ended questions. 
The study explored the students' opinions about the role of PBL in the form of the inter-disciplinary project in a language classroom. The students believed that the chosen topic of the project work was very interesting and appropriate for the future engineers' training (100\%). About $92 \%$ of them considered the project work as productive for the development of their future research career. However, the learners marked a number of difficulties they encountered when carrying out the project, such as: (1) preparing the report on future education and research career path $(50 \%)$; (2) defining a topic of the summary project of the proposed research $(66 \%)$; (3) formulating the aims and outcomes of the proposed research and putting them down in writing $(73 \%)$; (4) presenting the summary projects in English before the classroom audience $(46 \%)$.

Most of the students found that the project really helped them aware of their own EFL communication skills and improve their speaking, writing, reading, and listening skills applicable to the science research area of engineering training. About $58 \%$ of the students suggested further implementation of the inter-disciplinary project in the EFL course. As for the other part of the learners (42\%), they were uncertain in their reply to the question whether they wished to continue carrying out project work or not. They explained this by the difficulties that encountered when doing the project work.

\section{CONCLUSIONS}

Both qualitative and quantitative data allowed us to conclude that carrying out the inter-disciplinary project had a positive effect on the development of the students' EFL proficiency in the science research area of engineering activity.

First, the learners acquired a sufficient amount of new vocabulary which allowed them to increase the average length and appropriateness of responses, enrich the oral and written speech with a variety of vocabulary items relevant to their field of study.

Second, the students' grammar aspect of speaking and writing was largely improved due to mastering a variety of speech models and structures enabling them to perform oral and written communication effectively both in educational and science research areas.

Thirdly, the learners showed significant progress in reading and writing when asked to study and analyse the reading sources related to the topic of their proposed research in order to design their own technological products each having its specific characteristics and novelty at the present stage.

Fourthly, the findings also indicated that PBL enhanced the learners' skills to make use of technology, i.e. design power point presentations and make videos, which is a vital component of engineers' professional training.

The study also provides two important implications. First, it is of vital importance to include inter-disciplinary projects into the EFL course especially in such contexts where students can both practice a variety of communication skills and apply the content knowledge in the field of their study in a meaningful way. Second, the implementation of PBL in teaching EFL can really enhance students' self-confidence in using English as an important means of communication in various spheres of engineering activity.

However, the students' opinions revealed some limitations of the study. They found that more preparation should be done by the lecturer prior to each of the project work stages as this would allow them to have more time on memorizing new vocabulary items and using them in real life contexts, practising writing skills through preparation of reports, resumes, or summaries, as well as reading skills to acquire, analyse and synthesize information which was needed to compile a summary project and make a video presentation of the proposed research. Future studies may focus on using PBL activities to monitor and evaluate the development of students' communication skills in other spheres of engineering training.

\section{REFERENCES}

[1] M. J. Riemer, "Communication skills for the $21^{\text {st }}$ century engineer", in Global Journal of Engineering Education, published in Australia, vol. 11, no 1, 2007, pp. 89-100.

[2] T. Yu. Polyakova, Diversification of continuous foreign language professional training in engineering education. Doctorate's dissertation. Kaliningrad, 2011, 479 p.

[3] Edutopia (2013). Tech Forum. 21.12.2015. [Online]. Available: http://techlearning.com/default.aspx?tabid=67\&entryid=509

[4] T. J. Kloppenborg, M. S. Baucus, "Project management in local nonprofit organisations: Engaging students in problem-based learning", in Journal of Management Education, vol. 28, 2004, pp. 610-630. http://dx.doi.org/10.1177/1052562904266008

[5] D. L. Fried-Booth, Project work. Oxford: Oxford University Press, 2012, p. 6

[6] I. Tudor, Learner-centredness as Language Education. Cambridge: Cambridge University Press, 1996, p. 219

[7] J. Harmer, The Practice of English Language Teaching. Longman Publishing, 1998, p. 147

[8] Common European Framework of Reference for Languages: learning, Teaching, Assessment. 21.12.2015. [Online]. Available: http://www.coe.int/t/dg4/linguistic/cadre1 en.asp

[9] T. Armer, Cambridge English for Scientists. Student's Book. Cambridge: Cambridge University Press, 2011, pp. 6-13.

\section{AUTHORS}

Yu. Yu. Kovalyova, is with the National Research Tomsk Polytechnic University, Tomsk, 634050 Russia (email: yulia_kovalyova@tpu.ru).

A. V. Soboleva, is with the National Research Tomsk State University, Tomsk, 634050 Russia, (e-mail: sobolevasandra@tpu.ru).

A. T. Kerimkulov, is with the National Research Tomsk Polytechnic University, Tomsk, 634050 Russia, (e-mail: argen-96@mail.ru).

Submitted 29 December 2015. Published as resubmitted by the authors 27 February 2016. 